\title{
Where are the people? Refocusing political geography on populism
}

\section{Lizotte, Christopher Andrew}

2019-05

Lizotte , C A 2019 , ' Where are the people? Refocusing political geography on populism ' , Political Geography , vol. 71 , pp. 139-141 . https://doi.org/10.1016/j.polgeo.2018.12.007

http://hdl.handle.net/10138/303376

https://doi.org/10.1016/j.polgeo.2018.12.007

draft

Downloaded from Helda, University of Helsinki institutional repository.

This is an electronic reprint of the original article.

This reprint may differ from the original in pagination and typographic detail.

Please cite the original version. 


\section{Where are the people? Refocusing political geography on populism}

Populism, as a political phenomenon, is currently dominating media coverage and academic discussion due to its meteoric rise across the world. Geographers have contributed to this conversation with a small, but important body of work directly or indirectly engaging with populism in recent years. For instance, Hart's (2014) investigation into the intersections between hegemony, nationalism, and populist politics in post-Apartheid South Africa is one of the most prominent monographs by a geographer that contains a sustained engagement with populism as such. More recently, geographers have worked to nuance some of the spatial tropes concerning the current populist wave: Gordon (2018) examines intersecting factors that correlate with support for populism in Europe to test the "left behind by globalization" hypothesis, while Rossi (2018) challenges the conventional wisdom of a populist rural revolt against urban cosmopolitanism.

There are, of course, flourishing literatures in geography on topics that intersect with populist politics: nationalism (e.g. Koch \& Paasi, 2016), bordering (e.g. Rosière \& Jones, 2012), authoritarianism (e.g. Koch, 2013), and many more. However, work on populism per se remains somewhat fragmentary and episodic across the discipline. Nor have geographers given sustained attention to the recent string of electoral populist victories in North America and Europe. Indeed, populism was barely represented at the 2018 AAG meetings in New Orleans, with only six mentions of the word "populism" in the entire program. Political Geography has published several insightful ad-hoc commentaries on events such as Brexit, Trump's Electoral College win, and other highly visible manifestations of contemporary populist politics (for a longer commentary on Trump, see Bessner \& Sparke, 2017; for a more detailed look at Brexit, see Bachmann \& Sidaway, 2016; Jessop, 2017; Gordon, 2018). However, it seems odd that the populist springboards to these movements - UKIP and the Tea Party, respectively - went virtually ignored by geographers (in the case of the Tea Party, see Morrill \& Webster, 2015 and Vinadia, 2018 for exceptions). And in any case, these two events represent only a fraction of the worldwide populist turn. To date, there is no substantive debate about the place of populism in geography, how populism should be spatially thought through, or how populist electoral politics should be theorized in relation to other long-standing discussions in our discipline.

The question is, then, how can we, as political geographers, consolidate our existing scholarship and contribute towards the creation of a robust geographies of populism literature? Developing this work touches on ontological issues of how we conceptualize populism as a spatial phenomenon as well as empirical issues of what counts as evidence of populist politics. As a starting point, scholars have generally agreed that populism is about style and representation rather than substance (Moffitt, 2016). This style is constituted by performances that construct a noble "people" who stands against a corrupt "elite," with both "people" and "elite" being nodal points that can chain together any number of empty signifiers (Laclau, 2005). What geographers can add to this is a recognition that there are two distinct political geographies that feed into the elaboration of populist styles: first, the historical moment of convergence between a crisis of global capitalism, accelerated migration to the Global North, and intensifying distrust in supranational governance. Second, the increasing territorialization of populist discourse itself as dissatisfaction with globalization's mobilization of people, capital, and culture - and the elites who have benefited from this mobilization - is expressed through calls to spatially isolate, close off, and withdraw. That is, in settings as diverse as Sri Lanka, Poland, and Australia, we can pose questions such as: are populist movements depoliticizing, or repoliticizing, the overall global convergence towards a managerial politics of consensus under neoliberalism? How do the spatial distributions of their electoral support and campaigning strategies reflect a desire to bring politics to the people (cf. Agnew \& Shin, 2017)? And how do they employ territorial metaphors and imagery to construct the people's identity and articulate their grievances and aspirations?

A second task for geographers if we are to make analytically meaningful distinctions between true "grassroots" populism and the kind of populism that, as Gramsci (1971) says, fractions of the elite deploy to challenge the established order, is to rethink assumptions about space and the political as they intersect with populism. As Clark (2015) and Barnett (2012) have suggested, a prevailing tendency in contemporary critical political and urban geography has been to concentrate on "the political" as inherently agonistic in the tradition of Rancière and other theorists (Hewlett, 2007), and therefore reify democracy as radical democracy. True politics in this paradigm is conceptualized as being inherently insurgent and oppositional, and the residual is cast as post-political apathy (Swyngedouw, 2011) or reactionary political maneuvering. This view risks muddying attempts to distinguish between performances of populism, which can be found across a range of populist and mainstream political actors alike, and any actual democratic content of populist political processes (cf. Müller, 2014), which will be more elusive.

These and other debates point to an opportunity to further study the relationship between populist politics and the spaces in which it operates. This is especially the case given the pressing need to better understand the current success of far right and ethnonationalist movements in using populist tactics (Bonikowski, 2017), as well as under what conditions such movements are able to achieve a level of widespread appeal that causes populist rhetoric and tactics to "spill over" into center-right and center-left parties. The recent string of electoral victories by these groups can raise anxieties about an unknown "dystopian neo-fascist future looming on the horizon" (Benjaminsen, Buhaug, Grove, McConnell, \& Steinberg, 2018). We can begin to address this by becoming intellectually curious about "the revenge of the 
places that don't matter" (Rodríguez-Pose, 2018). It has become clear that to a large extent, recent populist sentiment and voting patterns have been a function not just of race, class, gender, and other social categories, but all of these refracted through place (Gordon, 2018; Gravelle, 2018; Rohla;Johnston;Jones;\& Manley, 2018). Spatial voting patterns are revealing that populist resentment is not simply a matter of material deprivation, but of places expressing their fear and outrage about potential futures in which they are economically and culturally irrelevant. As Moisio (2018) notes of the contemporary trend of "knowledge-based" economization, the political economic privileging of intellectual labor, urban diversity, and cultural liberalism "is not only characterized by the financial and political success of its "happy subjects' but also by its capacity to abandon certain populations and to situate them outside of political normativity" (161). These conditions become an effective entry point for the manufacture of "demographic fever dreams" (Gökarıksel; Neubert; \& Smith, forthcoming) that mobilize - however fleetingly and in incomplete a way - a territorialized demos that is willing to turn a blind eye to the most outrageous excesses of ethnonationalist policy in order to defeat imagined enemies who threaten what remains of its formerly privileged position.

I argue, then, that we need to continue to work towards a geographically-grounded approach to populism that accounts for how populist politics mobilizes material and symbolic grievances through narratives about place. To this end, there are three areas where geographers are already active that could be more explicitly tied to contemporary populist movements: the first is nationalism, a topic of long interest to geographers. In particular, work on the affective dimensions of national attachment and geopolitical imaginaries (Dittmer \& Gray, 2010; Militz \& Schurr, 2016) offers considerable potential for understanding more specifically how populist movements leverage emotions in conjunction with territorial narrative. Recent research in communication and media studies has highlighted the emotional rather than ideological aspects that activate support for populist goals and candidates (Bracciale \& Martella, 2017; Krämer, 2017); understanding how these tropes are expressed territorially would help us further appreciate how attachment to place fuels nationalist-populist resentment. Von Hierschhausen (2017) is a fascinating example in this regard, studying how memories of states and borders no longer in existence continue to fuel nationalist geographic imaginaries in contemporary Eastern Europe.

Second, geographies that explore the identities that are deployed in left-behind places as cultural resistance to despised "globalist" elitists. In the United States context, for instance, political scientists and historians have produced works of public scholarship that firmly grounds in place the cultural as well as economic disparities characterizing the "civilized" urban coasts and the "redneck" rural hinterlands, such as Cramer's (2016) The Politics of Resentment and Hochschild's (2016) Strangers in Their Own Land. Geographers can add to these important narratives by understanding the specifically territorial dimensions of populist cultural politics on their own terms. Work in geographies of religion provides exemplary critical scholarship in this regard that is simultaneously conscious of nuance, ambiguity, and internal dissent. For example, Dittmer (2008) explores American Evangelical geopolitical visions through the dystopian, post-Rapture film Left Behind, and Nagel and Ehrkamp (2016) investigate the limits of charity in the complex relationship between Christian identity and immigration politics.

Finally, resource nationalism, which has remained relatively unexplored by geographers (Koch \& Perrault, 2018), is an area of study that can provide grounded accounts of how populist movements shift and transform when they come to power in government. Andreucci (2017), for instance, explores the connections and contradictions of populist strategy in Bolivia under Evo Morales, which began with a strong radical environmental ethos. However, the government's increasing reliance on natural resources forced it to restructure its populist discourse to portray resource extraction as a natural right of the
Bolivian people and to exclude environmental and indigenous groups struggling against it. Similar dynamics are on display in Mongolia, where deep public anger over dispossession and inequality as a result of mining propelled populist presidential candidate Khaltmaa Battulga to victory (Myadar \& Jackson, 2018).

What this brief discussion has hopefully highlighted is that we, as a community of scholars, have a rich intellectual tradition upon which we can draw to understand one of the most urgent issues of our time. Populism in its contemporary manifestations did not arise from nowhere, has immediate and profound implications for our world, and will likely persist into the foreseeable future. We as geographers are well-equipped to rise to decode the spatial foundations of this phenomenon; it is up to us to rise to the challenge.

\section{Declarations of interest}

None.

\section{Fund}

This work was supported by the Academy of Finland RELATE Centre of Excellence in the Relational and Territorial Politics of Bordering, Identities and Transnationalisation, grant number 307348.

\section{Acknowledgements}

I would like to thank Natalie Koch, Sami Moisio, and Filippo Menga for their extremely helpful and illuminating comments and suggestions.

\section{Appendix A. Supplementary data}

Supplementary data to this article can be found online at https:// doi.org/10.1016/j.polgeo.2018.12.007.

\section{References}

Agnew, J., \& Shin, M. (2017). Spatializing populism: Taking politics to the people in Italy. Annals of the Association of American Geographers, 107(4), 915-933. https://doi.org/ 10.1080/24694452.2016.1270194.

Andreucci, D. (2017). Populism, hegemony, and the politics of natural resource extraction in Evo Morales's Bolivia. Antipode, 50(4), 825-845. https://doi.org/10.1111/anti. 12373.

Bachmann, V., \& Sidaway, J. (2016). Brexit geopolitics. Geoforum, 77, 47-50.

Barnett, C. (2012). Situating the geographies of injustice in democratic theory. Geoforum, 43, 677-686. https://doi.org/10.1016/j.geoforum.2011.03.002.

Benjaminsen, T., Buhaug, H., Grove, K., McConnell, F., \& Steinberg, P. (2018). Political geography in the impasse. Political Geography, 62, A1-A2. https://doi.org/10.1016/j. polgeo.2017.10.007.

Bessner, D., \& Sparke, M. (2017). Nazism, neoliberalism, and the Trumpist challenge to democracy. Environment \& Planning A, 49(6), 1214-1223. https://doi.org/10.1177/ 0308518 X17701429.

Bonikowski, B. (2017). Ethno-nationalist populism and the mobilization of collective resentment. British Journal of Sociology, 68(S1), S181-S213. https://doi.org/10.1111/ 1468-4446.12325.

Bracciale, R., \& Martella, A. (2017). Define the populist political communication style: The case of Italian political leaders on. Twitter. Information, Communication \& Society, 20(9), 1310-1329. https://doi.org/10.1080/1369118X.2017.1328522.

Clark, N. (2015). Geographies of politics and anti-politics. Geoforum, 62, 190-192. https://doi.org/10.1016/j.geoforum.2015.04.005.

Cramer, K. (2016). The politics of resentment: Rural consciousness in Wisconsin and the rise of scott walker. Chicago: Chicago University Press.

Dittmer, J. (2008). The geographical pivot of (the end of) history: Evangelical geopolitical imaginations and audience interpretation of Left behind. Political Geography, 27(3), 280-300. https://doi.org/10.1016/j.polgeo.2007.12.002.

Dittmer, J., \& Gray, N. (2010). Popular geopolitics 2.0: Towards new methodologies of the everyday. Geography Compass, 4(11), 1664-1677. https://doi.org/10.1111/j. 1749-8198.2010.00399.x.

Gökarıksel, B., Neubert, C., \& Smith, S. (forthcoming). Demographic fever dreams: Fragile masculinity and population politics in the rise of the global right. Signs: Journal of Women in Culture and Society $44,3$.

Gordon, I. R. (2018). In what sense left behind by globalisation? Looking for a less reductionist geography of the populist surge in Europe. Cambridge Journal of Regions, Economy and Society, 11, 95-113. https://doi.org/10.1093/cjres/rsx028.

Gramsci, A. (1971). In Q. Hoare, \& G. Nowell Smith (Eds.). Selections from the prison notebooks. New York: International Publishers Company. 
Gravelle, T. (2018). Politics, time, space, and attitudes toward US-Mexico border security. Political Geography, 65(1), 107-116. https://doi.org/10.1016/j.polgeo.2018.05.012.

Hart, G. (2014). Rethinking the South African crisis: Nationalism, populism, hegemony. Athens, Georgia, United States of America: University of Georgia Press.

Hewlett, N. (2007). Badiou, balibar, Rancière: Rethinking emancipation. (London: Continuum).

Hochschild, A. (2016). Strangers in their own land: Anger and mourning on the America right. Princeton, New Jersey: Princeton University Press.

Jessop, B. (2017). The organic crisis of the British state: Putting Brexit in its place. Globalizations, 14(1), 133-141. https://doi.org/10.1080/14747731.2016.1228783.

Koch, N. (2013). Sport and soft authoritarian nation-building. Political Geography, 32, 42-51. https://doi.org/10.1016/j.polgeo.2012.11.006.

Koch, N., \& Paasi, A. (2016). Banal nationalism 20 years on: Re-thinking, re-formulating and re-contextualizing the concept. Political Geography, 54, 1-6. https://doi.org/10. 1016/j.polgeo.2016.06.002.

Koch, N., \& Perrault, T. (2018). Resource nationalism. Progress in human geography. https:// doi.org/10.1177/0309132518781497 Advance online copy.

Krämer, B. (2017). Populist online practices: The function of the internet in right-wing populism. Information, Communication \& Society, 20(9), 1293-1309. https://doi.org/ 10.1080/1369118X.2017.1328520.

Laclau, E. (2005). On populist reason. London, United Kingdon: Verso.

Militz, E., \& Schurr, C. (2016). Affective nationalism: Banalities of belonging in Azerbaijan. Political Geography, 54, 54-63. https://doi.org/10.1016/j.polgeo.2015 11.002.

Moffitt, B. (2016). The global rise of populism: Performance, political style, and representation. Stanford, California: Stanford University Press.

Moisio, S. (2018). Geopolitics of the knowledge-based economy. Oxon, United Kingdom: Routledge.

Morrill, R. L., \& Webster, G. W. (2015). Spatial and political realignment of the U.S. electorate, 1988 - 2012. Political Geography, 48(1), 93-107. https://doi.org/10.1016/ j.polgeo.2015.07.002.

Müller, J.-W. (2014). The people must be extracted from within the people": Reflections on populism. Constellations, 21(4), 483-493. https://doi.org/10.1111/1467-8675. 12126.

Myadar, O., \& Jackson, S. (2018). Contradictions of populism and resource extraction: Examining the intersection of resource nationalism and accumulation by dispossession in Mongolia. Annals of the association of American geographers (Online advance copy).

Nagel, C., \& Ehrkamp, P. (2016). Deserving welcome? Immigrants, christian faith communities, and the contentious politics of belonging in the U.S. South. Antipode, 48(4), 1040-1058. https://doi.org/10.1111/anti.12233.

Rodríguez-Pose, A. (2018). The revenge of the places that don't matter (and what to do about it). Cambridge Journal of Regions, Economy and Society, 11(3), 189-209. https:// doi.org/10.1093/cjres/rsx024.

Rohla, R., Johnston, R., Jones, K., \& Manley, D. (2018). Spatial scale and the geographical polarization of the American electorate. Political Geography, 65(1), 117-122. https:// doi.org/10.1016/j.polgeo.2018.05.012.

Rosière, S., \& Jones, R. (2012). Teichopolitics: Re-considering globalisation through the role of walls and fences. Geopolitics, 17(1), 217-234. https://doi.org/10.1080/ 14650045.2011.574653.

Rossi, U. (2018). The populist eruption and the urban question. Urban Geographyhttps://doi. org/10.1080/02723638.2018.1448135 Advance online copy.

Swyngedouw, E. (2011). Interrogating post-democratization: Reclaiming egalitarian political spaces. Political Geography, 30(7), 370-380. https://doi.org/10.1016/j.polgeo. 2011.08.001.

Vinadia, R. (2018, September 24). Le dilemne du parti républicain dans le Wisconsin suite à l'éléction de Trump. Revue LISA/LISA e-journal, XVI(2), https://doi.org/10.4000/ lisa.9759.

Von Hirschhausen, B. (2017). Leçon des frontières fantômes: Les traces du passé nous viennent (aussi) du futur. L'Espace Géographique, (2), 97-105.

Christopher Lizotte ${ }^{\mathrm{a}, \mathrm{b}, \mathrm{c}, *}$

${ }^{a}$ University of Helsinki Department of Geosciences and Geography Spatial Policy, Politics, and Planning Research Group, P.O. Box 4 (Yliopistonkatu

3), 00014, Helsinki, Finland

${ }^{\mathrm{b}}$ Academy of Finland RELATE Centre of Excellence in Research in the Relational and Territorial Politics of Bordering, Identities and Transnationalisation, P.O. Box 4 (Yliopistonkatu 3), 00014, Helsinki,

Finland

${ }^{\mathrm{c}}$ Helsinki Institute of Urban and Regional Studies, P.O. Box 4 (Yliopistonkatu 3), 00014, Helsinki, Finland E-mail address: christopher.lizotte@helsinki.fi.

${ }^{*}$ University of Helsinki Department of Geosciences and Geography Spatial Policy, Politics, and Planning Research Group, P.O. Box 4 (Yliopistonkatu 3), 00014, Helsinki, Finland. 